\title{
Impactul Decretului nr. 195/2020 privind instituirea stării de urgență pe teritoriul României asupra contractelor guvernate de o lege străină (I)
}

Dan Petrache ${ }^{1}$

Rezumat: Acest studiu este redactat la începutul stării de urgență declarate la nivel național de Președintele României, din cauza pandemiei de Covid-19. Scopul lucrării este de a studia consecințele pe care Decretul nr. 195/2020 privind instituirea stării de urgență pe teritoriul României și actele normative subsecvente le au asupra contractelor cu element de extraneitate guvernate de o lege străină. Mai concret, vom analiza în ce măsură legea română interferează cu lex contractus, pentru acele convenții unde executarea obligațiilor va avea loc pe teritoriul României.

Cuvinte cheie: lege străină, contracte internaționale, stare de urgență.

The impact of Decree no. 195/2020 regarding the state of emergency established in Romania on contracts governed by a foreign law (I)

\begin{abstract}
This paper is written at the very beginning of a nationwide emergency state, declared by the Romanian President, due to the Covid-19 pandemic. The aim of this paper is to assess the effects that Presidential Decree no. 195/16.03.2020 regarding the state of emergency established in Romania and its subsequent legal acts have on international contracts governed by a foreign law. More specifically, we will analyze to what extent the Romanian Presidential Decree no. 195/2020 interferes with the foreign lex contractus, for those agreements that should be performed on Romanian territory.
\end{abstract}

Keywords: foreign law, international agreements, emergency state.

\section{Considerații introductive ${ }^{2}$}

§1. De regulă, legea aplicabilă contractului internațional este aleasă, expres sau tacit, de către părți ${ }^{3}$. Atunci când părțile nu au făcut o determinare a lex contractus, aceasta va fi identificată prin utilizarea normelor conflictuale de localizare obiectivă din Regulamentul nr. 593/2008 privind legea aplicabilă obligațiilor contractuale (Roma I) ${ }^{4}$.

\footnotetext{
${ }^{1}$ Managing Associate Popovici Niţu Stoica \& Asociații; colaborator al Facultăţii de Drept, Universitatea din București, la disciplinele Drept internațional privat și Dreptul comerțului internaţional.

${ }^{2}$ Prezentul material (publicat și în revista online a Facultăţii de Drept, Universitatea din București, AUBD Forum Juridic) reprezintă intervenția autorului în cadrul conferinței „Urgența în drept”, organizată de Facultatea de Drept a Universității din București, 30-31 martie 2020.

${ }^{3}$ „Contractul este guvernat de legea aleasă de către părți. Această alegere trebuie să fie expresă sau să rezulte, cu un grad rezonabil de certitudine, din clauzele contractuale sau din imprejurările cauzei. Prin alegerea lor, părțile pot desemna legea aplicabilă întregului contract sau numai unei părți din acesta." - Art. 3 alin. (1) Roma I. Pentru mai multe detalii, a se vedea A. Belohlavek, Convenția de la Roma. Regulamentul Roma I, Vol. I, C.H. Beck, București, 2012, pp. 676 și urm.; D.A. Sitaru, Drept internațional privat, C.H. Beck, București, 2013, pp. 335 și urm; I. Filipescu, A. Filipescu, Tratat de drept internațional privat, Universul Juridic, București, 2008, pp. 336 și urm; I. Macovei, Tratat de drept internațional privat, Universul Juridic, 2017, pp. 248 și urm.

${ }^{4}$ Denumit în continuare „Regulamentul Roma I” sau „Roma I”.
} 
În funcție de alegerea părților sau de soluția normei conflictuale ${ }^{5}$, contractul internațional poate fi guvernat de o lege străină ${ }^{6}$.

§2. În continuare, atenția noastră se va îndrepta asupra acestei realităţi juridice: contractele cârmuite de o lege străină.

Așa cum sugerează și titlul, obiectivul nostru este să evaluăm efectele pe care Decretul $n r$. 195/2020 privind instituirea stării de urgență pe teritoriul României (denumit în continuare „Decretul nr. 195/2020”) și actele normative subsecvente le produc asupra acestor convenții.

Decretul nr. 195/2020 a fost emis într-un moment de cumpănă pentru societatea noastră, amenințată de o epidemie care, la data finalizării prezentului material, a provocat peste 95.000 de decese în toată lumea ${ }^{7}$.

5 „,̂n măsura în care legea aplicabilă contractului nu a fost aleasă (...), legea aplicabilă contractului se determină după cum urmează:

(a) contractul de vânzare-cumpărare de bunuri este reglementat de legea țării în care își are reședința obișnuită vânzătorul;

(b) contractul de prestări servicii este reglementat de legea țării în care ișsi are reședința obișnuită prestatorul de servicii;

(c) contractul privind un drept real imobiliar sau privind dreptul de locatiiune asupra unui imobil este reglementat de legea țării în care este situat imobilul;

(d) fără a aduce atingere literei (c), contractul de locațiune având drept obiect folosința privată și temporară a unui imobil pe o perioadă de maximum șase luni consecutive este reglementat de legea țării în care își are reședința obișnnită proprietarul, cu condiția ca locatarul să fie o persoană fizică și să iși aibă reședința obișnuită în aceeași țară;

(e) contractul de franciză este reglementat de legea țării în care își are reședința obișnuită beneficiarul francizei;

(f) contractul de distribuție este reglementat de legea țării în care își are reședința obișnuită distribuitorul;

(g) contractul de vânzare-cumpărare de bunuri la licitație este reglementat de legea țării în care are loc licitația, dacă se poate stabili care este acest loc;

(h) orice contract încheiat în cadrul unui sistem multilateral, care reunește sau facilitează reunirea de interese multiple de vânzare-cumpărare de instrumente financiare ale terților, astfel cum sunt definite la articolul 4 alineatul (1) punctul 17 din Directiva 2004/39/CE, in conformitate cu normele nediscreționare, și care este reglementat de o lege unică, este reglementat de legea respectivă.

(2) În cazul în care contractului nu i se aplică alineatul (1) sau în care elementelor contractului li s-ar aplica mai multe dintre literele $(a)-(h)$ de la alineatul (1), contractul este reglementat de legea țării în care iși are reședința obișnuită partea contractantă care efectuează prestația caracteristică.

(3) În cazul în care din ansamblul circumstanțelor cauzei rezultă fără echivoc că respectivul contract are în mod vădit o legătură mai strânsă cu o altă țară decât cea menționată la alineatele (1) sau (2), se aplică legea din acea altă țară.

(4) În cazul în care legea aplicabilă nu poate fi determinată în temeiul alineatelor (1) sau (2), contractul este reglementat de legea țării cu care are cele mai strânse legături." - art. 4 Roma I.

${ }^{6}$ Avem în vedere regulile care guvernează fondul contractului. Legea aplicabilă formei contractului este supusă unui regim juridic lax. Astfel, conform art. 11 Roma I, contractul încheiat între prezenți sau între absenţi care se află în același stat la momentul încheierii contractului este valabil dacă respectă exigențele de formă (i) din lex contractus sau (ii) din legea de la locul încheierii sale. Iar contractul încheiat între absenți care se află în țări diferite la momentul încheierii contractului este valabil din punct de vedere formal dacă respectă (i) lex contractus sau (ii) legea oricăruia din statele în care una din părți sau reprezentanții acesteia se află la momentul încheierii contractului sau (iii) legea statului în care oricare dintre părți își avea reședința obișnuită la momentul încheierii contractului.

7 Conform datelor prezentate la adresa https://www.worldometers.info/coronavirus/, accesat ultima dată la 10.04.2020. 
§3. Nici Decretul nr. 195/2020, nici actele normative care i-au urmat nu conţin vreo dispoziție de drept internațional privat. Dar aceasta nu înseamnă că vorbim de reglementări fără relevanță pentru contractele internaționale.

De aceea, în cele ce urmează, vom studia consecințele pe care Decretul nr. 195/2020 le are asupra contractelor cu element de extraneitate ${ }^{8}$ guvernate de o lege străină. În această primă parte, vom analiza în ce măsură legea română interferează cu lex contractus, pentru acele convenții unde executarea obligațiilor va avea loc pe teritoriul României. În partea a doua, vom căuta să aflăm dacă Decretul nr. 195/2020 instituie sau creează premisele adoptării unor norme de aplicație imediată.

\section{Executarea contractelor guvernate de o lege străină pe teritoriul României}

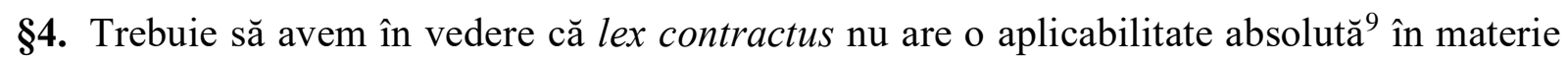
contractuală, ci coexistă cu alte sisteme de drept ${ }^{10}$, cum ar fi cel al instanței sesizate (lex fori) sau cel de la locul executării obligațiilor (lex loci executionis).

§5. Identificarea legii de la locul executării contractului implică, în mod logic, stabilirea locului executării. Conceptul de loc al executării obligației va trebui determinat pe baza clauzelor contractuale ${ }^{11}$. Trebuie avute în vedere toate clauzele relevante din contract, dar și uzanțele $^{12}$ sau obișnuințele stabilite între părți. În cazul în care contractul nu oferă o soluție, interpretarea noțiunii va fi făcută în conformitate cu prevederile lex contractus ${ }^{13}$.

În acest context, trebuie să avem în vedere și că noțiunea de loc al executării obligației beneficiază de o abundentă jurisprudență ${ }^{14}$ CJUE, în contextul reglementărilor Bruxelles. În materie contractuală, acestea atribuie o competență alternativă instanțelor de la locul

\footnotetext{
${ }^{8}$ Am precizat că ne vom referi la contractele cu element de extraneitate căci pentru contractele care își au toate elementele relevante în jurisdicția română, este incident art. 3 alin. (3) din Regulamentul Roma I, conform căruia: „In cazul în care toate elementele relevante pentru situația respectivă, în momentul în care are loc alegerea, se află în altă țară decât aceea a cărei lege a fost aleasă, alegerea făcută de părți nu aduce atingere aplicării dispozițiilor legii acelei alte țări, de la care nu se poate deroga prin acord." Așadar, normele imperative din legea română se vor aplica în continuare, în ciuda clauzei contractuale care trimite la un alt sistem de drept. Pentru o analiză detaliată privind acest text de lege, a se vedea A. Belohlavek, op. cit., pp. 715 și urm.

${ }^{9}$ Pentru o analiză a chestiunilor care nu se circumscriu sferei de aplicare a Regulamentului Roma I, a se vedea M.C. Niță, Aspecte esenţiale privind analiza şi interpretarea unor materii aparţinând domeniului de excludere al Regulamentului (CE) nr. 593/2008 (Roma I), Pandectele Române nr. 4/2017, Wolters Kluwer, București.

${ }^{10}$ M.-E. Ancel, P. Deumier, M. Laazouzi, Droit des contrats internationaux, Dalloz, Paris, 2017, p. 217.

${ }^{11}$ Art. 2558 alin. (5) C. civ.: „Când părţile au determinat ele insele inţelesul noţiunilor dintr-un act juridic, calificarea acestor noțiuni se face după voinţa părţilor."

${ }^{12}$ Cum ar fi, spre exemplu, regulile Incoterms.

${ }^{13}$ În acest caz, avem de-a face cu o calificare secundară. Calificarea secundară este cea care intervine după ce a operat calificarea principală și se face în temeiul legii aplicabile fondului cauzei (în cazul nostru, lex contractus). Astfel, calificarea secundară nu influențează legea aplicabilă, dar afectează soluția pe fond - D.A. Sitaru, op. cit., p. 64.

${ }^{14}$ Pentru analize ample ale acestei jurisprudențe, a se vedea Gh.-L. Zidaru, Competența in materie civilă potrivit Regulamentului Bruxelles I Bis (nr. 1215/2012), Hamangiu, 2017, pp. 136-170; Ș.-Al. Stănescu, Regulamentul (UE) nr. 1215/2012 adnotat cu explicații și jurisprudența CJUE, Hamangiu, 2015, pp. 48-91.
} 
executării contractului ${ }^{15}$. Cazuistica respectivă poate servi drept călăuză pentru a determina contractele considerate a se executa pe teritoriul României ${ }^{16}$.

În continuare, vom analiza cum se îmbină lex contractus cu lex loci executionis și lex fori în etapa executării contractului, pentru a determina dacă actele normative adoptate în contextul situației de urgență se aplică și contractelor guvernate de o lege străină.

\section{II.1 Domeniul de aplicare al lex contractus. Corelare cu lex loci executionis și lex fori}

§6. Conform art. 12 alin. (1) din Regulamentul Roma I, legea aplicabilă contractului reglementează, printre altele: ,(b) executarea obligațiilor născute din contract; (c) în limitele competenței conferite instanței sesizate de legea sa procedurală, consecințtele neexecutării totale sau parțiale a obligațiilor, inclusiv evaluarea prejudiciului (...);"’

Totuși, art. 12 alin. (2) Roma I face trimitere la legea de la locul executării contractului: „In ceea ce privește modalitatea de executare și măsurile care pot fi luate în cazul unei executări defectuoase, se va avea în vedere legea țării în care are loc executarea." Există două interpretări date acestui text de lege.

§7. Prima este că avem de-a face cu o normă conflictuală de excepție, derogatorie de la lex contractus. Altfel spus, legea locului de executare va guverna modurile și formalitățile de executare a contractului, dar și măsurile pentru remedierea sau restrângerea efectelor prejudiciabile ale contractului ${ }^{17}$. Practic, în aceste aspecte punctuale, vom utiliza regulile lex loci executionis, iar, în rest, ne raportăm la normele din lex contractus.

§8. A doua interpretare este că Regulamentul Roma I nu dorește substituirea competenței lex contractus cu cea a lex loci executionis. Lex contractus rămâne în principiu aplicabilă, dar instanța ar trebui să țină cont de legea de la locul executării contractului.

§9. Formularea textului - „se va avea în vedere” - susține această opinie. Dacă legiuitorul european ar fi vrut să instituie o normă conflictuală de excepție, ar fi utilizat o sintagmă de

\footnotetext{
${ }^{15}$ Conform art. 7 din Regulamentul Bruxelles I Bis: „O persoană care are domiciliul pe teritoriul unui stat membru poate fi acționată în justiție într-un alt stat membru: 1. (a) în materie contractuală, în fața instanțelor de la locul de executare a obligației în cauză; (b) în sensul aplicării prezentei dispoziții și în absența vreunei convenții contrare, locul de executare a obligației în cauză este: în cazul vânzării de mărfuri, locul dintr-un stat membru unde, în temeiul contractului, au fost sau ar fi trebuit să fie livrate mărfurile; în cazul prestării de servicii, locul dintr-un stat membru unde, în temeiul contractului, au fost sau ar fi trebuit să fie prestate serviciile; (c) în cazul în care nu se aplică litera (b), se aplică litera (a);"

${ }^{16}$ Considerentul nr. 7 din Preambulul Regulamentului Roma I: „Domeniul de aplicare material și dispozițiile prezentului regulament ar trebui să fie concordante cu Regulamentul (CE) nr. 44/2001 al Consiliului din 22 decembrie 2000 privind competența judiciară, recunoașterea și executarea hotărârilor în materie civilă și comercială (5) (Bruxelles I) și cu Regulamentul (CE) nr. 864/2007 al Parlamentului European și al Consiliului din 11 iulie 2007 privind legea aplicabilă obligațiilor necontractuale (Roma II).”

17 D.A. Sitaru, op. cit., pp. 396-397; I. Macovei, op. cit., p. 267: „Legea locului de executare va guverna, în principiu, următoarele elemente: modurile și formalitățile de executare a contractului; măsurile luate de creditor pentru preîntâmpinarea neexecutării obligațiilor contractuale; recepția cantitativă și calitativă a mărfurilor; măsurile pentru remedierea sau restrângerea efectelor prejudiciabile ale neexecutării."
} 
tipul „se va aplica”, ,sunt reglementate de”, așa cum a procedat în cazul celorlalte norme conflictuale din Regulamentul Roma ${ }^{18}$.

\$10. Totodată, analiza istorică a reglementării confirmă această interpretare.

Art. 10 alin. (2) din Convenția de la Roma din 1980 privind legea obligaţiilor contractuale, precursoarea Regulamentului Roma I, avea un conținut identic art. 12 alin. (2) Roma I. Iar Raportul care a însoțit adoptarea Convenției de la Roma menționează că judecătorul cauzei va aprecia dacă legea de la locul executării contractului are vreo relevanță pentru modalitatea în care care contractul trebuie executat și are discreție totală în a decide dacă să utilizeze normele respective pentru soluționare echitabilă a cauzei ${ }^{1920}$.

Ca atare, ne alăturăm celor care consideră că sensul art. 12 alin (2) din Regulamentul Roma I este de a autoriza instanța să aplice legea de locului executării, în acele situații în care aceasta impune anumite constrângeri în executarea obligațiilor ${ }^{21}$.

§11. Aceste constrângeri pot privi, spre pildă, îndeplinirea unor formalităţi, modalităti tehnice de punere în întârziere sau existența unor zile de sărbătoare legală care, în anumite circumstanțe, pot scuza întârzierile în executarea obligațiilor ${ }^{22}$.

De exemplu, dacă legea contractului impune ca punerea în întârziere să fie realizată de către o autoritate statală, aceasta înseamnă că punerea în întârziere pe teritoriul României va trebui realizată prin executor judecătoresc, pentru a respecta exigențele lex contractus $^{23}$.

Așadar, sensul textului este că atunci când aplică legea străină, instanța trebuie să o coreleze cu lex loci executionis. În contextul actual, limitările de circulație sau alte piedici în calea executării din legislația noastră, adoptate în contextul stării de urgență, constituie un element care ar trebuit să fie avut în vedere în contractele guvernate de o lege străină care urmează să fie executate pe teritoriul României.

\$12. O consecință a interpretării date art. 12 alin. (2) Roma I este că aspectele legate de neexecutarea conformă a obligațiilor contractuale se vor circumscrie lex contractus, iar nu lex loci executionis.

Mai concret, punerea în întârziere ${ }^{24}$, excepția de neexecutare (exceptio non adimpleti contractus) și regimul legal al daunelor-interese sunt guvernate de legea contractului.

\footnotetext{
${ }^{18} \mathrm{Nu}$ vorbim de o traducere defectuoasă, cum se întâmplă uneori în cazul regulamentelor sau directivelor europene. Versiunile în limba engleză și franceză utilizează sintagme similare: „regard shall be had”, respectiv „on aura égard”.

${ }^{19}$ M. Giuliano, P. Lagarde, Report on the Convention on the law applicable to contractual obligations, Article 10, J. Of., nr. C 282, 31.10.1980.

${ }^{20}$ Ibidem.

${ }^{21}$ A. Belohlavek, op. cit., p. 1695.

${ }^{22}$ M. Audit, S. Bollée, P. Callé, op. cit., pp. 174-175.

${ }^{23}$ Deși legea română permite punerea în întârziere prin orice mijloc de comunicare, această posibilitate nu va exista la îndemâna creditorului, față de dispozițiile lex contractus: „Dacă prin lege sau prin contract nu se prevede altfel, notificarea se comunică debitorului prin executor judecătoresc sau prin orice alt mijloc care asigură dovada comunicării”" - art. 1522 C. civ.
} 
Rezoluțiunea și rezilierea sunt de asemenea supuse lex contractus $^{25}$. În cazul rezoluțiunii/rezilierii extrajudiciare, declarația de rezoluțiune sau reziliere este un act unilateral de sine stătător. Pentru o abordare coerentă, acesta ar trebui să fie guvernat tot de lex contractus, ca lege cu care actul unilateral prezintă cele mai strânse legături ${ }^{26}$.

De asemenea, clauza de hardship este guvernată de lex contractus $^{27}$. Legea contractului determină validitatea sa ori poate oferi un mecanism legal de adaptare a contractului ${ }^{28}$.

§13. Notă discordantă fac măsurile asigurătorii. Măsurile conservatorii și asigurătorii, cum ar fi asigurarea de dovezi, sechestrul asigurător, poprirea asigurătorie, sunt reglementate de legea instanței sesizate $(\text { lex fori })^{29}$. Așadar, indiferent de legea aplicabilă contractului, instanța va putea impune doar acele măsuri prevăzute de propria legislație procesuală.

Pe lângă măsurile asigurătorii aplicabile și în litigiile pur interne, în cauzele transfrontaliere creditorul are la îndemână un mecanism suplimentar ${ }^{30}$, reprezentat de ordonanța asigurătorie europeană de indisponibilizare a conturilor bancare ${ }^{31}$.

\footnotetext{
${ }^{24}$ Pentru opinia contrară, a se vedea D.A. Sitaru, op. cit., p. 397; I. Macovei, op. cit., p. 267. Această interpretare era justificată în contextul Legii nr. 105/1992 privind reglementarea raporturilor de drept internațional privat. Conform art. 80 alin. (2) din Legea nr. 105/1992: „Modul de executare a obligațiilor izvorâte din contract trebuie să se conformeze legii locului de executare. Creditorul este obligat să respecte această lege în luarea măsurilor destinate, potrivit contractului, să preîntâmpine sau să remedieze neexecutarea ori să-i restrângă efectele prejudiciabile". Dat fiind că Regulamentul Roma I nu conține o prevedere similară, nu putem fi de acord că punerea în întârziere ar fi guvernată de o altă lege decât lex contractus.
}

${ }^{25}$ D.A. Sitaru, op. cit., p. 399.

${ }^{26}$ Art. 2637 alin. (1) C. civ.: „Condițiile de fond ale actului juridic sunt stabilite de legea aleasă de părți sau, după caz, de autorul său.”; art. 2638 alin. (1) C. civ.: „In lipsa alegerii, se aplică legea statului cu care actul juridic prezintă legăturile cele mai strânse, iar dacă această lege nu poate fi identificată, se aplică legea locului unde actul juridic a fost încheiat."

27 Clauza de hardship este o clauză contractuală care prevede obligația părților de a proceda la negociere în vederea readaptării contractului sau după caz, de a apela la un terț, eventual arbitru, în același scop, dacă pe parcursul derulării contractului anumite evenimente afectează semnificativ echilibrul contractual, independent de culpa oricăreia dintre părți, producând astfel o îngreunare substanțială a executării contractului pentru cel puțin una din părți, care ar fi inechitabil să fie suportată exclusiv de partea afectată - D.A. Sitaru, Dreptul comerțului internațional. Partea Generală, Universul Juridic, București, 2008, p. 493.

${ }^{28}$ Dacă lex contractus este legea română, dispozițiile art. 1271 alin. (2)-(3) C. civ. vor fi incidente: ,,(2) (...) dacă executarea contractului a devenit excesiv de oneroasă datorită unei schimbări excepţionale a împrejurărilor care ar face vădit injustă obligarea debitorului la executarea obligaţiei, instanţa poate să dispună:

a) adaptarea contractului, pentru a distribui în mod echitabil între părţi pierderile şi beneficiile ce rezultă din schimbarea imprejurărilor;

b) încetarea contractului, la momentul şi în condiţiile pe care le stabileşte.

(3) Dispoziţiile alin. (2) sunt aplicabile numai dacă:

a) schimbarea împrejurărilor a intervenit după încheierea contractului;

b) schimbarea împrejurărilor, precum şi întinderea acesteia nu au fost şi nici nu puteau fi avute în vedere de către debitor, în mod rezonabil, în momentul încheierii contractului;

c) debitorul nu şi-a asumat riscul schimbării împrejurărilor şi nici nu putea fi în mod rezonabil considerat că şiar fi asumat acest risc;

d) debitorul a încercat, într-un termen rezonabil şi cu bună-credinţă, negocierea adaptării rezonabile şi echitabile a contractului.",

${ }^{29}$, ,In procesul civil internațional instanța aplică legea procesuală română, sub rezerva unor dispoziții exprese contrare" - art. 1088 C. proc. civ.

${ }^{30}$ Ordonanța asigurătorie europeană este reglementată de Regulamentul (UE) nr. 655/2014 al Parlamentului European și al Consiliului din 15 mai 2014 de instituire a unei proceduri pentru ordonanța asigurătorie 
Desigur, trebuie ca instanțele române să soluționeze astfel de cauze în această perioadă. Consiliul Superior al Magistraturii (CSM), Secția pentru Judecători, a adoptat Hotărârea nr. 47 din 24.03.2020, prin care a indicat cauzele care ar trebui să fie soluționate pe durata stării de urgență. Printre acestea, se regăsesc atât măsurile asigurătorii, cât și asigurarea de dovezi. Dar conform art. 42 din Anexa nr. 1 a Decretului nr. 195/2020, teza finală, Hotărârea CSM nr. 47/24.03.2020 are caracter de recomandare pentru instanțe: „(...) Consiliul Superior al Magistraturii dă îndrumări, în vederea asigurării unei practici unitare, colegiilor de conducere ale instanţelor menţionate cu privire la modul de stabilire a cauzelor care se judecă pe durata stării de urgenţă."

De aceea, justiţiabilul trebuie să verifice în prealabil dacă instanța la care depune acțiunea va proceda la judecarea cererii în perioada următoare ${ }^{32}$.

\section{II.2 Incidența art. X alin. (2) şi (3) din OUG nr. 29/2020 asupra contractelor guvernate de o lege străină a căror executare se realizează pe teritoriul României}

§14. În continuare, vom analiza dacă două dispoziții aplicabile contractelor, adoptate prin OUG nr. 29/2020 privind unele măsuri economice şi fiscal-bugetare ${ }^{33}$, vor impacta și convențiile guvernate de o lege străină.

§15. Legea aplicabilă forței majore. Mai întâi, ne oprim atenția asupra art. X alin. (2) din OUG 29/2020. Conform acestuia, ,prin derogare de la alte dispoziții legale”, în contractele în derulare încheiate de întreprinderile mici sau mijlocii, forţa majoră poate fi invocată împotriva acestora numai după încercarea de renegociere a contractului în sensul adaptării sale ${ }^{34}$.

europeană de indisponibilizare a conturilor bancare în vederea facilitării recuperării transfrontaliere a datoriilor în materie civilă și comercială.

Regulamentul nr. 655/2014 instituie o procedură la nivelul Uniunii care permite unui creditor să obțină o ordonanță asigurătorie prin care să împiedice punerea în pericol a executării ulterioare a creanței creditorului prin transferul sau prin retragerea fondurilor, până la concurenţa cuantumului specificat în ordonanță, pe care îl deține debitorul sau care este deținut în numele lui într-un cont bancar deținut într-un stat membru.

În sensul Regulamentului nr. 655/2014, o cauză transfrontalieră este aceea în care contul bancar sau conturile bancare care urmează să fie indisponibilizate prin ordonanța asigurătorie sunt deținute într-un stat membru, altul decât: (a) statul membru al instanței sesizate cu cererea de emitere a ordonanței asigurătorii; sau (b) statul membru în care creditorul își are domiciliul (art. 3 alin. (1) din Regulamentul nr. 655/2014).

Competența de a emite o ordonanță asigurătorie aparține instanțelor din statul membru care au competența de a solutiona fondul.

Instanța emite ordonanța asigurătorie atunci când creditorul a prezentat probe suficiente pentru a convinge instanța că se impune de urgență o măsură asigurătorie sub forma unei ordonanțe asigurătorii, deoarece există un risc real ca, în lipsa unei astfel de măsuri, executarea ulterioară a creanței creditorului împotriva debitorului să fie împiedicată sau îngreunată în mod considerabil.

31 Art. 1 alin. (2) din Regulamentul nr. 655/2014 menționează expres că ordonanța asigurătorie se află la dispoziția creditorului ca alternativă la măsurile asigurătorii prevăzute în dreptul intern.

32 Spre exemplu, Hotărârea nr. 53 din 18.03.2020 a Colegiului de Conducere al Curții de Apel București nu menționează măsurile asigurătorii printre cauzele de urgență deosebită care se vor judeca pe durata stării de urgență.

33 Denumită în continuare „OUG nr. 29/2020”.

${ }^{34}$ Textul integral al art. X alin. (2) din OUG nr. 29/2020 este următorul: „Prin derogare de la alte dispoziţii legale, în contractele în derulare, altele decât cele prevăzute la alin. (1), încheiate de întreprinderile mici sau mijlocii prevăzute la alin. (1), poate fi invocată forţa majoră împotriva acestora numai după încercarea, dovedită cu înscrisuri comunicate între părţi prin orice mijloc, inclusiv prin mijloace electronice, de renegociere 
Această prevedere instituie o barieră adițională în calea invocării forței majore, în încercarea de a favoriza executarea contractului.

Doctrina este unanimă în privința încadrării cauzelor exoneratoare de răspundere în sfera de aplicare a lex contractus ${ }^{35}$.

Prin urmare, conținutul forței majore, regimul său de invocare și validitatea unei eventuale clauze de forță majoră vor fi guvernate de lex contractus care, prin ipoteză, este o lege străină. Ca atare, apreciem că prevederile art. X alin. (2) din OUG nr. 29/2020 nu vor fi incidente în cazul unor contracte guvernate o lege străină.

\$16. Prezumțiile legale. Apoi, art. X alin. (3) din OUG nr. 29/2020 instituie o prezumție legală în sensul existenței forței majore în cazul în care una din părți a obținut un certificat de situație de urgență de la autoritățile române ${ }^{36}$.

Prezumțiile legale pot fi calificate ca fiind o problemă de procedură, fiind de altfel uzual reglementate în legislațiile procesuale civile ale sistemelor de drept europene, caz în care acestea ar fi reglementate de legea instanței sesizate. Într-o altă abordare, prezumțiile legale țin de fondul raportului juridic întrucât au rolul de a determina drepturile și obligațiile părților ${ }^{37}$.

Regulamentul Roma I tranșează această problemă, prevăzând expres că: „Legea care reglementează o obligație contractuală în temeiul prezentului regulament se aplică în măsura în care cuprinde, în materia obligațiilor contractuale, norme care instituie prezumții legale sau repartizează sarcina probei." 38

Ca atare, rămânem în sfera de aplicare a lex contractus atunci când vorbim de prezumții legale. Ceea ce înseamnă că art. X alin. (3) din OUG nr. 29/2020 nu va fí incident în cazul convențiilor guvernate de o lege străină.

\section{II.3 Concluzii intermediare}

a contractului, pentru adaptarea clauzelor acestora cu luarea în considerare a condiţiilor exceptionale generate de starea de urgenţă."

${ }^{35}$ M.-E. Ancel, P. Deumier, M. Laazouzi, op. cit., p. 246.; D.A. Sitaru, op. cit., p. 399; I. Macovei, op. cit., p. 268 .

${ }^{36}$ Textul integral al art. X alin. (3) din OUG nr. 29/2020 este următorul: „Se prezumă a constitui caz de forţă majoră, $\hat{\imath}$ sensul prezentei ordonanțe de urgență, împrejurarea imprevizibilă, absolut invincibilă şi inevitabilă la care se referă art. 1.351 alin. (2) din Codul civil, care rezultă dintr-o acţiune a autorităţilor în aplicarea măsurilor impuse de prevenirea şi combaterea pandemiei determinate de infecţia cu coronavirusul COVID-19, care a afectat activitatea întreprinderii mici şi mijlocii, afectare atestată prin certificatul de situaţie de urgenţă. Prezumţia poate fi răsturnată de partea interesată prin orice mijloc de probă. Caracterul imprevizibil se raportează la momentul naşterii raportului juridic afectat. Nu vor fi imprevizibile măsurile luate de autorităţi în conformitate cu actul normativ care a instituit starea de urgenţă."

37 „Această calificare este justificată, deoarece, în măsura în care privesc obligații contractuale, atât prezumțiile legale, cât și modul de repartizare a sarcinii probei între creditor și debitor au rolul de a determina obligațiile părților" - D.A. Sitaru, op. cit., p.393.

${ }^{38}$ Art. 18 din Regulamentul Roma I. 
Față de cele prezentate anterior, concluziile pe care le putem trage la finalul primei părți sunt următoarele:

- dacă executarea are loc pe teritoriul României, instanța va avea în vedere prevederile din legea română atunci când acestea influențează executarea obligațiilor contractuale, având discreție totală cu privire la aplicarea acestora.

- Nu există obligația de a aplica lex loci executionis în locul lex contractus ori de a utiliza în mod concomitent lex contractus și lex loci executionis.

- Remediile neexecutării contractului, cauzele exoneratoare de răspundere, precum și prezumțiile legale sunt guvernate de lex contractus. Prin urmare, art. X alin. (2) și (3) din OUG nr. 29/2020 nu vor fi incidente atunci când lex causae este o lege străină.

- Legea română va fi aplicabilă ca lex fori în cazul măsurilor asigurătorii care sunt solicitate instanțelor române.

Materialul a fost publicat în revista online a Facultății de Drept, $\underline{\text { AUBD - Forum Juridic }}$ nr. $1 / 2020$. 